Using Lesson Study to Integrate Information Literacy Throughout the Curriculum

Angie Stombaugh, PhD, RN, FNP-BC, Rita Sperstad, EdD, MSN, RN, Arin VanWormer, PhD, RN, ACNSBC, Eric Jennings, MA, Hans Kishel, MS,MS, Bryan Vogh, MA

Authors' Affiliations: Assistant Professor (Dr Stombaugh, Dr Sperstad, Dr VanWormer) College of Nursing and Health Sciences, University of Wisconsin-Eau Claire, Eau Claire, WI. Assistant Professor (Mr Jennings, Mr Kishel, Mr Vogh), Library Services, University of Wisconsin-Eau Claire, WI

Corresponding Author: Dr Stombaugh, University of Wisconsin-Eau Claire, 105 Garfield Avenue, Eau Claire, WI 54702 (stombaam@uwec.edu)

This is a non-final version of an article published in final form in:

Stombaugh, Angie, Rita Sperstad, Arin VanWormer, Eric Jennings, Hans Kishel, and Bryan S. Vogh. "Using Lesson Study to Integrate Information Literacy Throughout the Curriculum." Nurse Educator 38, no. 4 (2013): 173-177. 


\begin{abstract}
The purpose of this article is to describe the process of developing an information literacy curriculum for a cohort of students over a 5 semester nursing program using lesson study. The overall goal was to enable undergraduate nursing students to retrieve various levels of scholarly information, evaluate its usefulness, and apply to clinical practice, thus demonstrating the development of evidence-based practice skills.
\end{abstract}


Using Lesson Study to Integrate Information Literacy Throughout the Curriculum Accrediting agencies, professional and national organizations are require nursing programs to prepare undergraduate nurses to demonstrate application of evidence-based practice (EBP) concepts towards improvement of patient outcomes (1-5). However, nursing faculty and librarians noticed that students still need an understanding of how to effectively retrieve, evaluate, and use information. Without information literacy skills that are critical in nursing programs, these students cannot effectively develop the skill of EBP and its application in practice.

Our undergraduate nursing program needed to strengthen EBP and information literacy skills in individual classes and across the curriculum. An interdisciplinary team of library and nursing faculty was created to address this problem and lesson study methodology was implemented to specifically address information literacy skill building and to facilitate incorporation of EBP concepts across the nursing curricula. Lesson study, a unique pedagogical method, was selected because of resident expertise, current experience using the lesson study methodology by library faculty, and the lack of evidence in the literature of using the lesson study method in a nursing context. This article will focus on the lesson study approach and how it was used to infuse information literacy across an undergraduate nursing curriculum.

\section{Our Problem}

Throughout their academic education, nursing students are expected to develop an ability to retrieve evidence-based resources, analyze information, and implement practical interventions when using this evidence with patient care. However, in teaching our nursing students about EBP skills, we found that beginning students lacked the ability to search and retrieve information related to patient care topics. Midlevel students were unable to choose appropriate sources to help them change and direct patient care decisions. Similarly, senior level students were unable to critically evaluate the quality each of the sources retrieved and place these articles within the level of evidence hierarchy. Conclusively, we identified a clear need for information literacy skills in the practice toward EBP of the beginning professional nurse. 
The nursing faculty analyzed the current practice of teaching information literacy related to EBP in the curriculum and identified several problems. First, we tended to teach in silos. The information taught at the sophomore level was not built upon; instead at the junior level content was repeated with only slight additions. Nursing faculty often asked librarians to come teach information literacy skills, but offered them little direction. Also, the library faculty were not teaching specific to the discipline of nursing, but rather providing a broad overview of retrieval skills. Cumulative Index of Nursing and Allied Health Literature (CINAHL) was introduced but students were uncertain how it related to specific retrieval skills needed for EBP assignments and projects. Finally, students were often lectured to and did not have an opportunity to apply these skills within the classroom. Nursing and library faculty recognized the need for a systematic collaborative approach to information literacy skills across the nursing curriculum.

\section{Literature Review}

The team decided to explore literature related to lesson study and information literacy related to EBP in nursing curriculum. Our hope was to build an understanding of lesson study and to explore how information literacy has been incorporated into curriculum related to EBP to help us reshape our teaching.

\section{What is Lesson Study?}

The underpinning of lesson study, first developed for use in Japanese elementary schools, is to move from the idea of "teaching as telling to teaching for understanding." (6). A lesson study gathers a group of instructors together to "plan, observe, and analyze actual classroom lessons, drawing out implications both for the design of specific lessons and for teaching and learning more broadly" (7, p. 273). There are generally 2 reasons for instructors to use a lesson study: to see how their teaching supports student attainment of the course goal(s) and/or improve student engagement and their understanding of how students learn (8).

A lesson study is a 5 step cycle. First, the group reads relevant literature about the topic that will be taught and discusses the class' objective(s) as desired by the group. Based on the readings and class 
objective(s), the group identifies one or more goals for the lesson study. Second, the group plans the session. Third, one member from the group teaches the session and other members take notes while observing the students. This is to evaluate the effectiveness of the planned session based on student engagement and understanding. Additional data on the effectiveness of the session can be gathered through a variety of assessment methods such as focus groups and surveys. Fourth, the group reviews all evaluative material and discusses the findings. Fifth, based on the findings, the group revises (if needed) the original session and implements the lesson study cycle again. Table 1 provides a summary of the steps, definitions and time commitment of this cycle.

Table 1. Lesson Study Method

\begin{tabular}{|c|c|c|}
\hline Lesson Study Steps & Definition & $\begin{array}{l}\text { Estimated Number of } \\
\text { meetings (45-90 } \\
\text { min)(7) }\end{array}$ \\
\hline $\begin{array}{l}\text { 1. Identify goals of lesson } \\
\text { study session }\end{array}$ & $\begin{array}{l}\text { Group reviews \& discusses literature, } \\
\text { identifies needs for class session, and } \\
\text { defines goals of specific lesson study } \\
\text { session to be taught. }\end{array}$ & $1-3$ \\
\hline $\begin{array}{ll}\text { 2. } & \text { Plan the lesson study } \\
\text { session }\end{array}$ & $\begin{array}{l}\text { Group plans a single lesson study } \\
\text { session based upon identified goals }\end{array}$ & $3-6$ \\
\hline $\begin{array}{l}\text { 3. Teach and observe the } \\
\text { lesson study session }\end{array}$ & $\begin{array}{l}\text { Member(s) of group teaches lesson } \\
\text { study session. Other members observe } \\
\text { students in class. }\end{array}$ & 1 \\
\hline $\begin{array}{l}\text { 4. Discuss findings from } \\
\text { lesson study session }\end{array}$ & $\begin{array}{l}\text { Group meets to discuss data collected } \\
\text { during lesson study session (focus } \\
\text { group questions, observations of } \\
\text { students) }\end{array}$ & 1 \\
\hline $\begin{array}{l}\text { 5. Revise the lesson study } \\
\text { session }\end{array}$ & $\begin{array}{l}\text { Based upon the discussion, group may } \\
\text { choose to adjust the lesson study } \\
\text { session and run again. }\end{array}$ & $1-2$ \\
\hline
\end{tabular}

Teaching lesson study as a curriculum development method for undergraduate education students to implement into K-12 classrooms has been used for some time (9). However, the use of lesson study in higher education is a more recent phenomenon. One of the first college-level lesson studies was piloted in a mathematics, statistics and computer science department (10). More recently, Watson and colleagues explored using lesson study as a method of collaboratively building a one-time information literacy instructional session between English faculty and librarians (11). The ease of using the lesson study methodology for various topics and across disciplines in higher education was strength that seemed to suitable for information literacy skills and EBP in the nursing curriculum. 
Information Literacy

The American Library Association defines information literacy as the ability to "recognize when information is needed and have the ability to locate, evaluate, and use effectively the needed information" (12, par. 3). Information literacy provides an ideal bridge between the technology of informatics and the evidence retrieval skill required in the process of EBP. Information literacy is often taught with EBP (13) and research links the two concepts. In some schools of nursing information literacy skills are taught in the first course, such as introducing EBP in a freshman year course (14). Nursing faculty and librarians worked collaboratively to introduce database searching, retrieval and review of articles related to a clinical problem. Formal evaluation was not done but the authors reported that assignments demonstrated success in learning basic EBP skills. Courey et al. created assignments in one course to link information literacy skills with specific clinical issues (15). These students were able to retrieve clinical information more effectively compared to the control group.

Another study by Shorten et al. evaluated faculty and librarians teaching information literacy skills across the curriculum (16). Results revealed nursing students had higher confidence in their own information literacy skills and performed better on a range of objective measures as compared to the control group. A similar study explored information literacy in a graduate program (17). Five core nursing courses were created by nursing faculty and librarians that focused on information literacy and strategies for evaluating strength of evidence. Results showed that students demonstrated an increase in information literacy competencies after completion.

There has been limited research in nursing education related to information literacy and EBP and how best to incorporate these concepts. Based on the literature findings, our group decided we needed a way to create and evaluate our instructional sessions since these concepts are important but we lack evidence on how best to teach them.

\section{The Lesson Study Project}


Definitions of and General Structure of a Lesson Study

This paper uses many terms. In order to enhance clear understanding of the process, we will use the following definitions:

- Lesson Study Project: A multi-year, scaffolded implementation of 3 lesson studies

- Lesson Study Project Group (LSPG): The group of 6 members (3 nursing faculty, 3 library faculty) that planned and executed the lesson study methodology

- Lesson Study Session: The single class period in which a member(s) of the LSPG taught and carried out the agreed upon plan.

- Lesson Study: The 5 steps involved in completing an iteration of a lesson study.

Using lesson study as a framework for organization, the following describes the process that our group underwent for this project.

\section{Building a Team}

The Center for Excellence in Teaching and Learning (CETL), funded by the Provost's office, was lookingfor additional people to work projects that used lesson study. This office contacted nursing faculty because of previous heavy involvement in other CETL initiatives. The director of CETL had prior success in facilitating lesson study in other disciplines on campus, two of which had involved library faculty. He explained the theoretical basis and collaborative nature of lesson study while highlighting the benefits of nursing faculty collaborating with librarians. The nursing faculty, recognizing the EBP information gap in their students and national standards increasingly stressing EBP, saw the Lesson Study Project as an opportunity to more broadly integrate the concepts of EBP and information literacy in the classroom. The three nursing faculty who collaborated on this project, represented the sophomore, junior and senior course levels of the curriculum where lesson study session would occur. Subsequent to the nursing faculty's acknowledged interest in pursuing lesson study, CETL contacted the library's nursing department liaison to see if he would be interested in working with nursing on lesson study. After accepting the invitation, the library's nursing liaison approached two colleagues with experience in lesson study and/or working with the nursing department. The director of CETL found a time for all Lesson Study Project participants to meet so that they could begin an orientation to lesson study. 


\section{Orientation to Lesson Study Project}

In order to begin collaborating, the director of CETL facilitated a sharing session in which he described what lesson study is and its history at this institution while librarians involved in previous lesson study projects shared personal insights and experiences with lesson study. This jump-started the Lesson Study Project for our group. Without the facilitator and librarian expertise with lesson study, the initial 2-hour meeting would have been woefully inadequate. Nursing faculty left the first meeting with an understanding of previous lesson study projects' goals and objectives as well as prior lesson study session plans used at this university. Before the second meeting, the purpose of which was to set a goal(s) for the Lesson Study Project, nursing faculty reviewed the materials from the first meeting and looked through their curriculum to identify specific classes that would benefit from lesson study.

\section{Goal Setting}

The second meeting of the Lesson Study Project focused on goal setting. The lesson study methodology suggests beginning this process by reviewing discipline-specific literature related to teaching and student learning. Faculty in nursing shared concerns with librarians about student performance on exams and in clinical, that students were not using EBP best practices. Librarians, whose literature is rife with articles on information literacy deficiencies in students, noticed many nursing students needing an inordinate amount of one-on-one instruction when working with nursing literature for their classes. The Lesson Study Project group identified an overlap between these two issues resulting in 2 initial goals for the Lesson Study Project. These goals were improving information literacy skills (library) and integrating EBP across the nursing curriculum (nursing). Because the nursing goal could not be accomplished in one lesson study session (as is typically done), the group decided to implement the lesson study methodology progressively across the nursing curriculum.

Through a process of refinement over several meetings, the LSPG came up with the overall goal for the Lesson Study Project: students will be able to retrieve various levels of scholarly information and evaluate its usefulness to clinical practice demonstrating development of skill in EBP. Over the course of a 
semester of bi-monthly meetings and sporadic meetings during the summer, the group collaboratively identified that a scaffolded, multi-year approach across the curriculum was needed with sessions being taught in the sophomore, junior, and senior year nursing curriculum. Students enter the nursing program year-round as sophomores in cohorts of about 50. Cohorts stay together throughout their matriculation, taking the same courses in sequence. During this period we began planning the first of the three lesson study session (sophomore-level) which was slated to be taught by one of the librarians in the LSPG in the fall semester.

\section{Teaching Our Lesson Study Project's Sessions}

One course during a student's first semester (sophomore) in the nursing program was targeted for the lesson study sessions. (See Table 2). Another sophomore course was identified as a prerequisite for the sophomore session. The goal for the prerequisite class was that students demonstrate understanding of nursing information structure and literature. The basis for this goal was suggested from one of the librarians who had participated in a previous lessons study on campus. One of the outcomes from this previous lesson study suggested a need to cover the structure and nature of literature in a discipline before teaching students how to find, evaluate and retrieve it. The goal of our Lesson Study Project at the sophomore level was exactly that; for students to find evaluate and retrieve information. The LSPG unanimously supported the rationale for this prerequisite class.

Table 2. Nursing/ Library Lesson Study Plan

\begin{tabular}{|c|c|c|c|}
\hline Nursing Class & Overall Goal & Lesson Study & Evaluation \\
\hline $\begin{array}{l}\text { Sophomore } \\
\text { (Prerequisite } \\
\text { Information) }\end{array}$ & $\begin{array}{l}\text { The student will be able } \\
\text { to retrieve various level } \\
\text { of scholarly information } \\
\text { and apply or evaluate its } \\
\text { usefulness to clinical } \\
\text { practice }\end{array}$ & $\begin{array}{l}\text { * Differentiate popular vs. } \\
\text { scholarly resources, } \\
\text { primary \& secondary } \\
\text { resources, per review vs. } \\
\text { non-peer reviewed pieces } \\
\text { of literature } \\
\text { * Identifies the value and } \\
\text { differences of variety of } \\
\text { formats of resources } \\
\text { (databases, websites) }\end{array}$ & $\begin{array}{l}\text { Baseline survey } \\
\text { assessment }\end{array}$ \\
\hline Sophomore & $\begin{array}{l}\text { The student will } \\
\text { demonstrate effective } \\
\text { search strategies to } \\
\text { retrieve one scholar } \\
\text { piece of evidence from } \\
\text { CINAHL to support their } \\
\text { clinical PICO question. }\end{array}$ & $\begin{array}{l}\text { * Constructs an information } \\
\text { seeking process (identify } \\
\text { key words, synonyms, } \\
\text { related words for } \\
\text { information needed to } \\
\text { assist with search } \\
\text { strategies) }\end{array}$ & $\begin{array}{l}\text { Observations of facultyl } \\
\text { students during lesson } \\
\text { study } \\
\text { Focus group post lesson } \\
\text { study } \\
\text { Embedded questions in } \\
\text { course exam }\end{array}$ \\
\hline
\end{tabular}




\begin{tabular}{|c|c|c|c|}
\hline & & $\begin{array}{l}\text { * Implements effective } \\
\text { search strategies to find } \\
\text { evidence for PICO clinical } \\
\text { question }\end{array}$ & \\
\hline Junior & $\begin{array}{l}\text { The student will } \\
\text { demonstrate advance } \\
\text { search strategies to } \\
\text { select high quality pieces } \\
\text { of evidence to support } \\
\text { their conical PICO } \\
\text { question. }\end{array}$ & $\begin{array}{l}\text { *Distinguishes the levels of } \\
\text { evidence } \\
{ }^{*} \text { Appreciate the value and } \\
\text { distinctions of expanded } \\
\text { resource formats (meta- } \\
\text { analyses, systematic } \\
\text { reviews) } \\
\text { *Implements advanced } \\
\text { search strategies in finding } \\
\text { evidence for PICO } \\
\text { question }\end{array}$ & $\begin{array}{l}\text { Observations of facultyl } \\
\text { students during lesson } \\
\text { study } \\
\text { Focus group post lesson } \\
\text { study } \\
\text { Embedded questions in } \\
\text { course exam }\end{array}$ \\
\hline Senior & $\begin{array}{l}\text { The student will } \\
\text { demonstrate using } \\
\text { advance search } \\
\text { strategies to select "best } \\
\text { practice:" evidence to } \\
\text { nursing practice within } \\
\text { the clinical setting. }\end{array}$ & $\begin{array}{l}\text { *Search/access review } \\
\text { (PubMed database, } \\
\text { National Clearing house, } \\
\text { Medline Plus) } \\
\text { *Implement application of } \\
\text { advanced searches to } \\
\text { clinical issue or problem }\end{array}$ & $\begin{array}{l}\text { Observations of faculty/ } \\
\text { students during lesson } \\
\text { study } \\
\text { Focus group post lesson } \\
\text { study } \\
\text { Embedded questions in } \\
\text { course exam }\end{array}$ \\
\hline
\end{tabular}

During the prerequisite course, students worked with a packet of articles that encompassed the various types of nursing literature - popular, scholarly, primary, and secondary articles - in this way, students would distinguish characteristics that make each of the articles fit a specific category. The librarian also defined peer review and covered how to identify the parts of a citation. Additional resources provided to the students included a handout created by the nursing professor describing general characteristics of nursing literature and a website that captured the information that was covered in class. A few weeks after this prerequisite class, the LSPG taught the sophomore-level lesson study session.

\section{Sophomore level lesson study session}

The sophomore level lesson study session's goal was that students demonstrate effective search strategies to retrieve one scholarly piece of evidence from CINAHL to support their clinical Population, Intervention, Control, Outcome (PICO) question. In small groups, students generated a PICO question prior to class. At the start of the session, students were provided a worksheet as a resource and as a means for the interactive exercise during the session. The librarian began the session by describing an example PICO question from the worksheet, created search terms using the PICO question, conducted a 
search in CINAHL and briefly demonstrated the use of limits and other techniques for refining a search in retrieving a scholarly piece of evidence for the PICO question. Working in groups, students mirrored this process with their own PICO question and recorded the process on their worksheet. While students completed the worksheet, the librarian and nursing faculty member were available for questions and assistance. The session ended with the librarian leading a general class discussion of how students found and accessed their scholarly piece of evidence and addressed common problems they encountered.

\section{Junior level lesson study session}

The junior lessons study session's goal was that students demonstrate advanced search strategies to select high quality pieces of evidence to support their clinical PICO question. Similar to what was done in the sophomore-level session; students came to class with a PICO question and completed an in-class worksheet. The task of the student small groups included searching for pieces of evidence in three databases beyond CINAHL; including PsycINFO, MEDLINE, Nursing Reference Center, Mosby's Nursing Consult, and the library's federated database search. Specific criteria for the scholarly evidence were given: published in the last 7 years, primary research, and a nurse as an author. Then students compared the results of their evidence from the various databases with the criteria provided. Finally, the class discussed the pros and cons of these resources in terms of their value to answer their PICO question.

\section{Senior level lesson study session}

The senior lessons study session's goal was that students will demonstrate advanced search strategies to select "best practice" evidence to nursing practice within the clinical setting. This class session builds on the previous lesson study sessions and will provide senior students with skills to find EBP resources when working in settings that do not have access to traditional library resources. In groups, students created a PICO question related to either a problem identified in an acute care experience or in their community based experience. Using the identified PICO question, students are instructed to independently search the databases that are available to the public (PubMed database, National Clearinghouse, Medline Plus) and retrieve "best practice" evidence applicable to their PICO question. 
The students, faculty and librarian then discussed the advantages and disadvantages of utilizing these resources to inform clinical practice.

\section{Observing Our Lesson Study Sessions}

A critical step in a lesson study is assessment. Unique to lesson study is the observation of the actual session by LSPG members and peers, who may be non-lesson study project group members. The assessment questions and formats were developed by the LSPG. When teaching each session, observers are scattered throughout the room, recording student engagement and participation in the session. Since data was being collected as part of a research study, Institutional Review Board approval was obtained. All participants at various course levels provided written consent to participate in this study. The observers looked for behaviors such as student engagement during the session and with the instructor. For example, were the students following along during the demonstration period of the session or were they doing something else on their computers? Are students actively participating in their groups? Do students have enough time to complete the in-class assignment?

Another assessment technique is focus groups. The LSPG conducted focus groups after each lesson study session with self-selected members of the cohort. The focus group participants were given pizza as an incentive for participation. The focus group was led by a member of the LSPG but was not that lesson study session's or course's instructor. Other LSPG members took notes during the focus group. The purpose of the focus group was to gather qualitative feedback on the effectiveness of the lesson study session. Several focus group sample questions include: Do you feel like you got all the information you needed out of the library session? When you have another research assignment, what strategies did you learn today that you will be able to use again?; What aspects of the lesson should be changed to improve your learning?

\section{Discussing and Revising Our Lesson Study Sessions}

One week after each lesson study session was taught, LSPG members meet to discuss the lesson study session observation notes and student responses to focus group questions. All group members, including 
the instructor(s) discussed themes that emerged from the data. Based upon the results of this discussion, the group decided whether the lesson study session had achieved the defined goal and if the teaching process needed refinement.

The purpose of revising a lesson study session is to enhance, and maximize student learning and engagement. Although this group has not changed any of its originally identified goals, it has enhanced each session's pedagogical approach based on the data returned. For example, after the sophomore level lesson study session, changes were made to the student worksheet to enhance the clarity of directions and ease of following and completing the form. Similarly, after the junior level lesson study session, changes were made to the worksheet, including shortening the introductory lecture and examples. Both of these revised lesson study sessions have clarified the problems observed by LSPG members and identified by students in the focus groups and enhanced the teaching/learning process.

\section{Longitudinal Assessment of a Scaffolded Lesson Study Project}

Unique to the LSPG's implementation of lesson study is a longitudinal analysis of cohorts of students in a nursing program. Surveys were administered to sophomore and senior students prior to the implementation of the lesson study sessions. The purpose of the initial sophomore survey was to gather baseline data so that the cohorts entering the lesson study sessions could be compared with their final post-lesson study (senior-level) survey. A post survey was administered to a control group of senior-level students who did not have any formal lesson study instruction were given at the start of the lesson study to determine a baseline. In addition to the pre and post surveys, assessment was also integrated into each class. Each course gathered data from embedded questions during course-specific multiple-choice questions in exams after the lesson study session was done. (See Table 2).

\section{Conclusion}

The lesson study method is an ideal way to implement a scaffolding approach of teaching information literacy skills toward evidence-based practice outcomes. This project was innovative in that it facilitated a multi-year, close collaboration between nursing and library faculty, and fostered an ongoing relationship 
between disciplines. Participating faculty valued this lesson study's interdisciplinary collaboration of teaching toward common student learning outcomes with a strong focus on student engagement. All members provided input into the lesson study, tailoring the information to meet the needs of the students from both nursing and library perspectives. The cyclical nature of a lesson study and this group's unique scaffolded implementation will continue to encourage improvement of information literacy and evidencebased practice across the nursing curriculum. 
References

1. American Association of Colleges of Nursing. The Essentials of Baccalaureate Education for Professional Nursing Practice. Washington DC: American Association of Colleges of Nursing; 2008.

2. Institute of Medicine. Crossing the Quality Chasm: A New Health System for the $21^{\text {st }}$ Century. Washington DC: National Academy Press; 2000.

3. National Council of State Boards of Nursing. 2013 NCLEX-RN Test Plan. Chicago: National Council of State Boards of Nursing, Inc; 2012.

4. National League for Nursing, Board of Governors. Position statement: preparing the next generation of nurses to practice in a technology-rich environment: An informatics agenda. 2008; Available at http://www.nln.org/aboutnln/positionstatements/informatics 052808.pdf

5. Quality and Safety Education for Nurses Overview. Available at www.qsen.org/overview. Accessed October 20, 2012.

6. Lewis C. The essential elements of lesson study. Northwest Teacher. 2003; 4(3):6-8.

7. Lewis C, Perry R, Hurd J, O'Connell M. Lesson study comes of age in North America. Phi Delta Kappan. 2006;88(4): 273-281.

8. Cerbin B. Lesson Study: Using Classroom Inquiry to Improve Teaching and Learning in Higher Education. Sterling, VA: Stylus; 2011.

9. Cohan A, Honigsfeld, A. Incorporating 'lesson study' in teacher preparation. Educ Forum. 2006; 71(1): 81-92.

10. Becker J, Ghenciu P, Horak M, Schroeder, H. A college lesson study in calculus, preliminary report. International Journal of Mathematical Education in Science \& Technology. 2008; 39(4): 491-503.

11. Waston, SE, Rex C, Markgraf J, Kishel H, Jennings E, Hinnant K.. Revising the "one-shot" through lesson study: Collaborating with writing faculty to rebuild a library instruction session. Coll Res Libr, In press.

12. American Library Association. Presidential Committee on Information Literacy: Final Report. 1989; Available at http://www.ala.org/acrl/publications/whitepapers/presidential 
13. Flood, L. S., Gasiewicz, N., \& Delpier, T. (2010). Integrating information literacy across a BSN curriculum. J Nurs Educ. 2010; 49(2): 101-104.

14. Burns HK., Foley SM. Building a foundation for an evidence-based approach to practice: Teaching basic concepts to undergraduate freshman students. J Prof Nurs. 2005; 21(6): 351-357.

15. Courey T, Benson-Soros J, Deemer K., Zeller, RA. The missing link: Information literacy and evidence-based practice as a new challenge for nurse educators. Nursing Education Perspectives. 2006; 27(6): 320-323.

16. Shorten A, Wallace MC, Crookes, PA. Developing information literacy: A key to evidence-based nursing. Int Nurs Rev. 2001; 48(2): 86-92.

17. Jacobs SK., Rosenfeld P, Haber J. Information literacy as the foundation for evidence-based practice in graduate nursing education: a curriculum-integrated approach. J Prof Nurs. 2003; 19(5): 320-328. 